\title{
Reflection on The Ausubel's Theory Application (ATA) in Basic Grammar Mapping (BGM) For Teaching Arabic Text Reading Skills
}

Wazzainab Binti Ismail, Ku Fatahiyah Binti Ku Azizan, Awatif Binti Abdul Rahman, Hairun Najuwah Binti Jamali, Hafida Mohamed Nordin

To Link this Article: http://dx.doi.org/10.6007/IJARBSS/v12-i1/12169 DOI:10.6007/IJARBSS/v12-i1/12169

Received: 17 November 2021, Revised: 21 December 2021, Accepted: 03 January 2022

Published Online: 27 January 2022

In-Text Citation: (Ismail et al., 2022)

To Cite this Article: Ismail, W. B., Azizan, K. F. B. K., Rahman, A. B. A., Jamali, H. N. B., \& Nordin, H. M. (2022). Reflection on The Ausubel's Theory Application (ATA) in Basic Grammar Mapping (BGM) For Teaching Arabic Text Reading Skills. International Journal of Academic Research in Business and Social Sciences, 12(1), $1407-1416$.

Copyright: (c) 2022 The Author(s)

Published by Human Resource Management Academic Research Society (www.hrmars.com) This article is published under the Creative Commons Attribution (CC BY 4.0) license. Anyone may reproduce, distribute, translate and create derivative works of this article (for both commercial and non0-commercial purposes), subject to full attribution to the original publication and authors. The full terms of this license may be seen at: http://creativecommons.org/licences/by/4.0/legalcode

Vol. 12, No. 1, 2022, Pg. 1407 - 1416

Full Terms \& Conditions of access and use can be found at http://hrmars.com/index.php/pages/detail/publication-ethics 


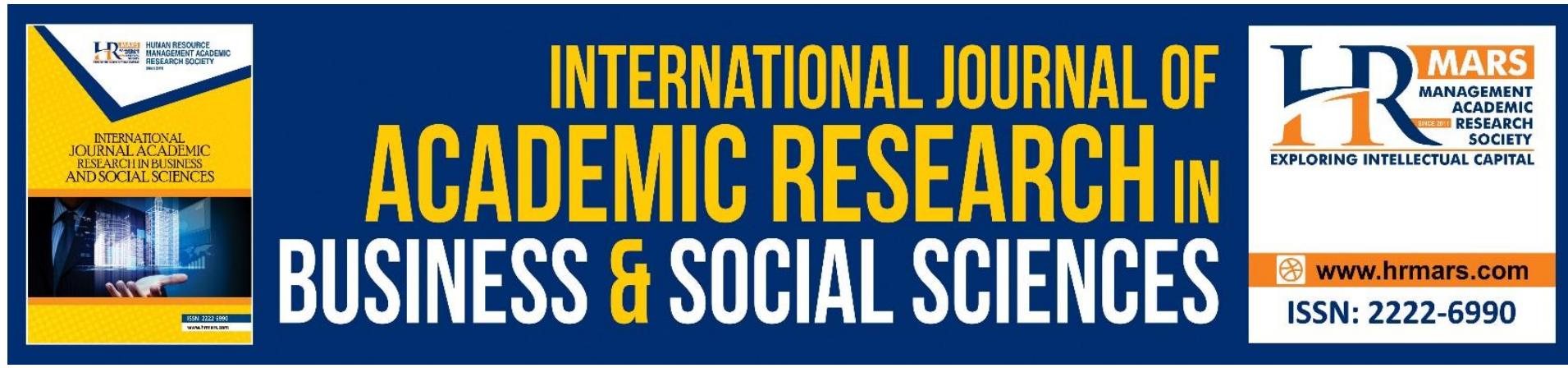

\title{
Reflection on The Ausubel's Theory Application (ATA) in Basic Grammar Mapping (BGM) For Teaching Arabic Text Reading Skills
}

\author{
Wazzainab Binti Ismail, Ku Fatahiyah Binti Ku Azizan, Awatif \\ Binti Abdul Rahman, Hairun Najuwah Binti Jamali, Hafida \\ Mohamed Nordin \\ Department of Languages and Human Development, Centre for Core Studies, \\ Kolej Universiti Islam Antarabangsa Selangor, KUIS, Malaysia
}

Email: wazzainab@kuis.edu.my

\begin{abstract}
One of Ausubel's Theory criteria is the process of combining and relating current information to existing knowledge that students already have. Thus, this theory can encourage students to think about the basic information of Arabic Grammar that they have learned and then reuse the information during learning activities. Therefore, this study seeks to answer the question and problem about the students making mistakes constantly on the pronunciation of the last letter of the Arabic word in reading Arabic text. The objective of the study is to examine the relationship between the Ausubel's Theory and Basic Grammar Mapping (BGM) to assist the process of reading Arabic texts. This study will also explain about the reflection of Ausubel's Theory Application (ATA) on the implementation of Basic Grammar Mapping (BGM) while reading Arabic texts. The methodology of the study is by observation and simple test of reading skills. The findings of the study explain that the reflection of Ausubel's Theory Application (ATA) during the implementation of Basic Grammar Mapping (BGM) when reading Arabic texts has a positive effect on the mastery of Arabic grammar such as i'rab, improves reading skills and inculcates critical thinking activities.
\end{abstract}

Keywords: Reflection, Ausubel, Basic Mapping, Pronunciation, Arabic Text

Introduction

Researchers and educators continue to create creative and innovative content in improving the quality of teaching and learning reading skills. There are many types of researches were conducted to mobilize student's mastered the skills of reading Arabic materials. The reason for these studies is to identify the weakness of students in mastering the skills of reading Arabic materials. These reading materials are more focused on written materials. Written materials are books, e-books, magazines and others written in Arabic should be read correctly according to the grammatical procedure of the Arabic language. The main Arabic language sciences that have a relationship with reading skills are morphology and syntax (Al-Tahanuwi, 1996). These two sciences are also known as Arabic grammar and they 
are important in reading activities (Hussin et al., 2016). Taimah (1986) states that method of teaching and learning activity is a situation where the role of teacher and student is equally important. Thus, a teacher must think and be creative in helping students to be more motivated in learning and comprehending reading skill of Arabic text. In the process of reading second language reading material or mastering the target language there is a need to master the text (Smith, 2004). Unfortunately, students make mistakes constantly on the pronunciation of the last letter of the Arabic word in reading Arabic text and this problem creates the objective of the research as stated below.

Research objectives:

1- To express the relationship between the Ausubel's Theory and Basic Grammar Mapping (BGM) to assist the process of reading Arabic texts.

2- To explain the reflection of Ausubel's Theory Application (ATA) on the implementation of Basic Grammar Mapping (BGM) while reading Arabic texts.

Many pieces of research emphasize the importance of improving teaching styles to elucidate the technique of teaching Arabic reading skills. Mohamed et al (2004) in their research entitled: Problems of Teaching Arabic Grammar among undergraduate students, encourage the students to do more exercises to detect accuracy and errors in the use of language from the reading materials. The materials of teaching should help students memorize the contents of Arabic grammar. Lecturers should strive to diversify the techniques and methods of teaching. Here shows the relation between the mastery of Arabic grammar and the performance of reading skills. The research ends with a suggestion asking for the creativity of teaching Arabic grammar which helps students read Arabic texts.

Another related study entitled: Improving Basic Arabic Text Reading Skills Through Quran Reading Skills and Drill Methods. The problem of the studies is merely the same where the students still doing mistakes when reading written materials. The limitation of the studies is the topics of Arabic Grammar Al-jarr, Zoraf and Mudhafun ilaih. Research methodologies used are interviews, observations, questionnaires, and the pre and post-test. The material used is the Quran. The Quran is a noble and primary source of reference for Islam which has the guidance of Islam. The Quran was originally not a written reading material but a sacred message to be heard, understood, and applied in real life. The Quran has now written with a completely lined and information for the words sound. This study chooses the implementation of various activities involving the discussion of the reason of the word sound to master the relevant grammatical topics then improve reading skills. The findings showed that the level of understanding increased (Mustafa et al., 2012).

In addition, to answer the suggestion of the research written stated by Mohamed et al (2004) and to enhance another angle of improvement for the studies by Mustafa et al (2012), another strongly related study is by (Ismail et al., 2021). The title is Teaching Arabic Text Reading Skills Using Unzur Qablahu (UQ) Technique: A Study of The Application of Cognitive Theory (ACT). The Unzur Qablahu (UQ) technique means looking at the previous word to help students know the pronunciation of the next word. This study is conducted to answer questions related to the weakness of students in determining word pronunciation when reading a text. Therefore, this Unzur Qablahu (UQ) technique approach is to assist the reading skill of Arabic texts. In addition, the study also examines the relevance of Unzur Qablahu (UQ) technique and the Application of Cognitive Theory (ACT). The research methodology is based on observation during the process of teaching Arabic text reading skills. The observation also records the conditions such as intonation, fluency, attitude, and other input as the reading process takes place. The findings of the study showed that the Unzur 
Qablahu (UQ) technique and the Application of Cognitive Theory (ACT) help the process of reading Arabic texts critically.

Therefore, in this current study, students will be asked to map and rearrange their previous information as stated in the meaning learning of Ausubel. The limitation of the study is the topics of Arabic Grammar Al-jarr and Mudhafun ilaih. There are the groups of Majrurat. Students may use the Unzur Qablahu (UQ) technique and the Application of Cognitive Theory (ACT). But another approach of this recent study is an elaboration of the words through the Basic Grammar Mapping (BGM) and then categorized accurately and not only to see the previous words.

\section{Literature Review}

\section{Ausubel's Theory of Meaningful learning}

Meaningful learning defines by Ausubel (1968): "the most important single factor influencing learning is what the learner already knows". Therefore, meaningful learning, which implies longer retention than memorizing, occurs when humans relate new concepts to pre-existing familiar concepts. Then changes are produced in our cognitive structure, concepts are modified and new links are created. It is a useful tool because it enables real learning, generates greater retention, and facilitates transferences to other real situations (Hansen, 2009; Vallori, 2014).

Then Vallori (2014) had listed the essential principles to do meaningful learning. These principles encourage open discussion to all learners, promote motivation and intelligence's imagination then apply the concept of mapping to help learners link and connect the information and concepts.

The Ausubel theory also inspired the concept of "Advance organizers" which are pedagogic devices that bridge the gap between what learners already know and what learners need to know (Gurlitt, 2012). Meaningful learning of some scientific laws or principles, for example, might imply a combinatorial form of meaningful learning (Moreira, 2011)

\section{Teaching Arabic Text Reading Skills}

In order to create creativity and innovation in language teaching and learning, comprehension and mastery of reading materials among students stated by Rahman et al (2016) argue that students need to be exposed to reading materials that can provide input and impact towards the construction of active, critical and creative thinking levels. Reading sources, on the other hand, need to be obtained from various sources that are accurate, clear, detailed and factual information. Mastery of these reading materials and resources requires effective techniques to increase students' interest in the reading material. These techniques can be introduced to students as an alternative to increase interest in reading material. This is because, if students do not know how to master the reading material through the techniques introduced, students will become passive and pessimistic about the reading material.

According to Muhammad et al (2012) primary, intermediate, and advanced level teaching measures should be introduced to address the problem of Arabic reading proficiency and learning styles, as well as suggest the introduction of intensive and extensive forms of reading. Ku et al (2014) stated that a balanced form of language learning curriculum by combining the intertwining of language branches to enhance language skills among students. 
It is to emphasis on drill methods and continuous reading practice and encourages the use of various teaching aids in the teaching of reading skills.

The ability to read is a very valuable skill and is a dynamic process, which requires active and meaningful communication between the reader and the writer. Reading is also said to be a person's ability to recognize visual forms and connect between forms and sounds and through experience as well as being able to interpret their meaning. Reading comprehension depends on a combination of language knowledge, cognitive and reading experience ( $\mathrm{Ku}$ et al., 2017).

\section{Basic Grammar Mapping (BGM) and The Reflection Of The Application Of Ausubel Theory (ATA)}

One of Ausubel's Theory criteria is the process of combining and relating current information to existing knowledge that students already have. Thus, this theory can encourage students to think about the basic information of Arabic Grammar that they have learned and then reuse the information during learning activities. Therefore, this study seeks to answer the question and problem about the students making mistakes constantly on the pronunciation of the last letter the Arabic word in reading Arabic text.

Therefore, teaching activities need to be renewed and diversified to attract students. Among the Arabic learning and teaching initiatives is by using mind maps. The idea has been popularized by Buzan (2006) as a mind map. Therefore, it is seen that many studies supported the use of mind maps in teaching Arabic and have succeeded in giving a positive impact (Widodo, 2016; Asyiah, 2016; Yulistri, 2015; Falah, 2014; El-Haq, 2012).

Therefore this recent study will use Basic Grammar Mapping (BGM) as an approach to help students master Arabic grammar. In addition, to map the functions that supports critical and creative digestion in students. This study is based on Ausubel's Theory Application (ATA) that encourages students to think about the basic information of Arabic grammar that has been learned at the secondary school level to be remembered, digested and mastered better.

\section{Research Design}

This is a qualitative research. The methodology of the study is through observation and simple test of reading skills (Darussalam \& Hussin, 2016). The study respondents are 10 students of Bachelor of Islamic Studies, International Islamic University College Selangor (Kolej Universiti Islam Antarabangsa Selangor, KUIS) from Arabic language class NBWU1022 (Al-Arabiah Al-A'liyah Li Dirasat Islamiyyah I). This course code is an Arabic language subject offered to Bachelor of Islamic Studies students in semester one. The justification in the choice of respondent is because they have a strong background in Arabic grammar as they were students of the Islamic studies stream. Some of them are diploma or matriculation in Islamic Studies graduates.

Firstly the preliminary study was held roughly in the class to identify the grammatical errors of respondents reading Arabic texts. As they were students of Arabic background from the secondary school, diploma, foundation or matriculation levels, they should not make many grammatical errors, especially the basic Arabic grammar. Thus, the implementation of the study observation was designed by supplying to the respondents the text from the Arabic language module book for NBWU1022 course code prepared by the Arabic language lecturers from the Center for Core Studies, KUIS. The respondents were given one day to read the selected text correctly. The next day, they cameto the class and read the text. The notes were made on the grammatical errors made by the respondents. The type of error seen was on the 
pronunciation of the last letter of the word based on some basic grammar. The limitation of the basic Arabic grammar topic was the law of Majrurat. Majrurat is one of the Arabic basic grammar rules that shows the way to recite the last letter of some conditions of the words. This study will focus on two types of Majrurat. Firstly, the nouns that came after the letter of al-Jarr and secondly, types of Idhafah or Mudhafun ilaih.

Preliminary observations included recording the mistakes made by the respondent on these two types of the Majrurat while they were reading the text. This is basic grammar yet the students recite the sound of the last letter wrongly. It showed that they read without thinking on the basic information of grammar that they had learned before. Thus, the study insists to help the respondents in reading texts by fostering appropriate techniques to detect basic Arabic grammar.

The researchers suggested the construction of Basic Grammar Mapping (BGM) to recognize the basic Arabic grammar. This Basic Grammar Mapping (BGM) is based on the Ausubel's Theory Application (ATA) to assist Arabic reading skills. As it was mentioned before that some of Ausubel's Theory criteria is the process of combining and relating current information to existing knowledge that students already have. Thus, this theory encourages students to think about the basic information of Arabic Grammar that they have learned and then reuse the information during learning activities. Thus, the Basic Grammar Mapping (BGM) is the reflection of the Ausubel's Theory Application (ATA). This mapping requires the students to analyse each word of Majrurat. This is because the information of the Majrurat is the basic rule in Arabic grammar that most students already know. The problem occurs when students ignore this rule while reading the text. So this study will usher the students to think first on the basic grammar that they have before reading the text. Then the Majrurat from type one and two were identified appropriately. As a result respondents can easily see the types of Majrurat.

To conclude, the researchers chose Basic Grammar Mapping (BGM) together with Ausubel's Theory Application (ATA) for respondents to remember again the information that they have before and apply while reading the text.

In the application of this method, the respondents were given a simple mind mapping example and were asked to understand the map. The observations were made, and there were discussion activities, information seeking and thinking. Upon completion of the activity of understanding and functioning the Basic Grammar Mapping (BGM), respondents were given a text to read. The observations explained that the respondents were eager to use the basic map even though some still lacked understanding. Yet the discussion between the respondents helped improve the activity of reading the text correctly and smoothly.

Figure 1: Basic Grammar Mapping Model (BGM) and the Ausubel's Theory Application (ATA) to assist the process of reading Arabic texts.

$$
\text { يعد استخدام الإنترنت في التعليم أمرا ضروريا. }
$$




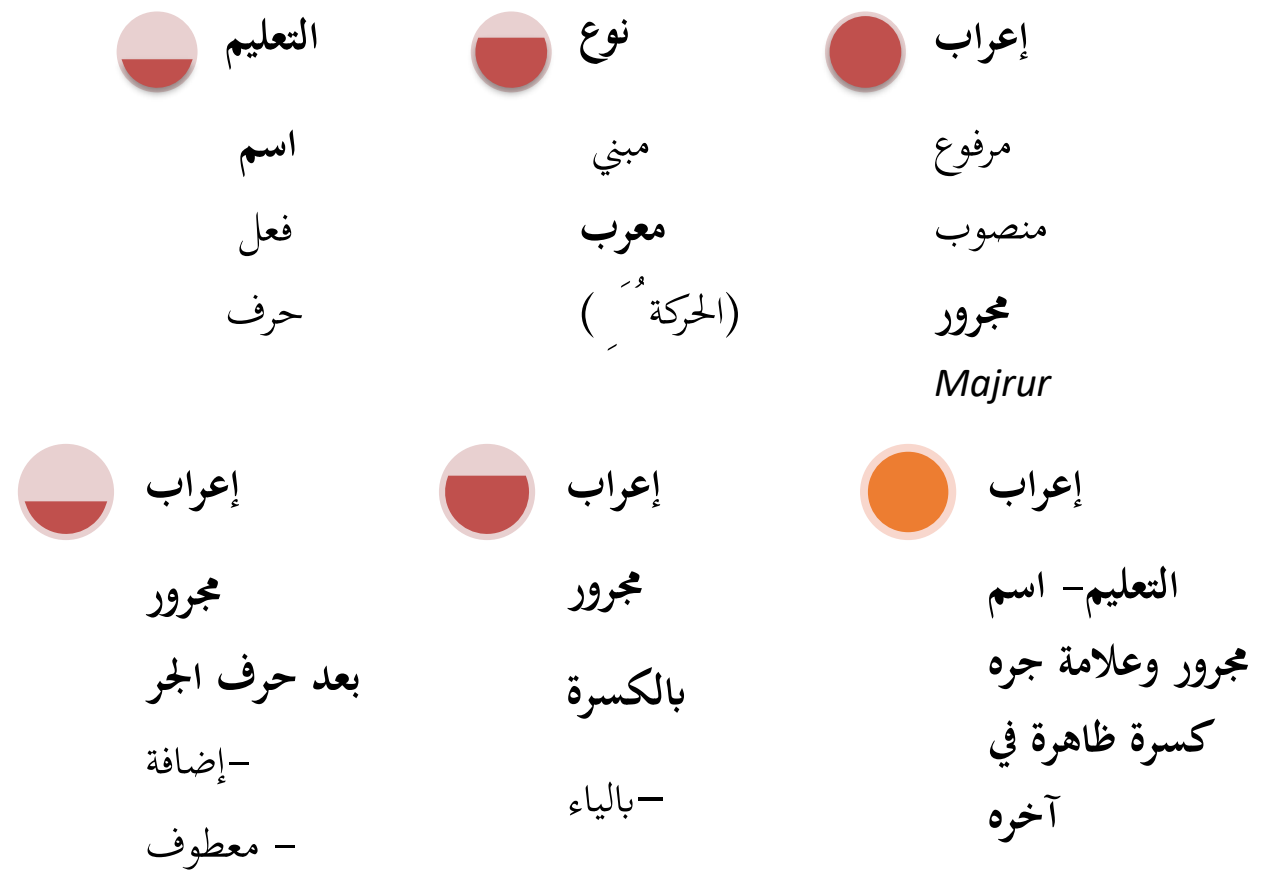

The diagram shows the developmental steps in understanding type one of Majrurat. This Basic Grammar Mapping (BGM) helps students to know the group of information of the word with the Ausubel's Theory Application (ATA) which encourages students to think, divide and connect existing grammatical information in order to increase understanding of the word and read the word correctly.

\section{Findings and Discussion}

The following is a simple observation and test conducted to list the findings of using Basic Grammar Mapping (BGM) along with Ausubel's Theory Application (ATA).

\begin{tabular}{|c|c|c|c|}
\hline \multirow{2}{*}{ 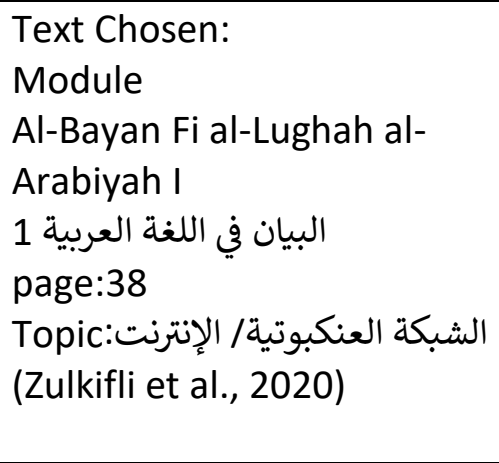 } & \multicolumn{3}{|c|}{ 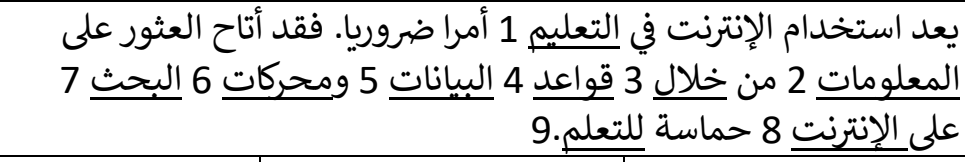 } \\
\hline & $\begin{array}{l}\text { Preliminary } \\
\text { Observations }\end{array}$ & $\begin{array}{l}\text { Observations } \\
\text { During the Basic } \\
\text { Grammar Mapping } \\
\text { (BGM) Discussion }\end{array}$ & $\begin{array}{l}\text { Observations } \\
\text { After the } \\
\text { Understanding of } \\
\text { the Basic } \\
\text { Grammar } \\
\text { Mapping (BGM) }\end{array}$ \\
\hline Text Reading Activity: & $\begin{array}{l}\text { Read without } \\
\text { thinking of } \\
\text { the } \\
\text { appropriate } \\
\text { sound of the. } \\
\text { words } 1-9\end{array}$ & $\begin{array}{l}\text { Read, discuss and } \\
\text { make BGM and } \\
\text { think about the } \\
\text { reason for the } \\
\text { word sound. } \\
\text { Discussion only for } \\
\text { Word } 1 \text { التعليم } \\
\text { because for other } \\
\text { words students }\end{array}$ & $\begin{array}{l}\text { Read fluently and } \\
\text { think of } \\
\text { appropriate } \\
\text { sound. } \\
\text { For the word 1-9 }\end{array}$ \\
\hline
\end{tabular}




\begin{tabular}{|c|c|c|c|}
\hline & & $\begin{array}{l}\text { can make their } \\
\text { own maps and try } \\
\text { to understand the } \\
\text { reason while } \\
\text { reading the text } \\
\text { later.(see figure } 1 \text { ) }\end{array}$ & \\
\hline $\begin{array}{l}\text { Notes: } \\
\text { A1-A10: Students } \\
\text { 1-9: Number of correct readings } \\
\text { for words 1-9 }\end{array}$ & $\begin{array}{l}A 1: 1 / 9 \\
A 2: 0 / 9 \\
A 3: 2 / 9 \\
A 4: 2 / 9 \\
A 5: 3 / 9 \\
A 6: 3 / 9 \\
A 7: 5 / 9 \\
A 8: 1 / 9 \\
A 9: 7 / 9 \\
A 10: 7 / 9\end{array}$ & - & $\begin{array}{l}\text { A1:5/9 } \\
\text { A2:5/9 } \\
\text { A3:6/9 } \\
\text { A4:7/9 } \\
\text { A5:4/9 } \\
\text { A6:5/9 } \\
\text { A7:8/9 } \\
\text { A8:5/9 } \\
\text { A9:8/9 } \\
\text { A10:9/9 }\end{array}$ \\
\hline
\end{tabular}

The findings of the study explain that the use of Basic Grammar Mapping (BGM) along with Ausubel's Theory Application (ATA) help the process of reading Arabic texts. It also has a positive effect on the mastery of Arabic grammar such as i'rab, improve reading skills and inculcate critical thinking activities.

\section{Conclusion}

The combination of Basic Grammar Mapping (BGM) and the reflection of the Ausubel's Theory Application (ATA) is the approach used for students to increase their understanding on the reason for word sounds while reading a text. Apparently, this shows that the current study is the expansion of The Unzur Qablahu (UQ) technique and the Application of Cognitive Theory (ACT). Moreover other related researches indeed contribute to students mastering the skills of reading the text correctly. It is a fact that each language has its own rules and regulations. The statement in the rules of Majrurat is remains, but the things that need to be discussed and implemented continuously are the structure while presenting the language rules and unchangeable facts. The implementation uses a simplified technique and interesting approach. The creativity of applying expert theories to improve the teaching and learning style is in accordance to the needs and the students' intellectual level. Yet every improvement and new approach used requires consistent application. As advised by the Muslim famous ulama Imam Al-Shafie R.A, a descendant of Rasulullah (p.b.u.h), the six conditions for seeking knowledge are intellect, determination, variation of effort, ability, teacher/lecturer guidance and long life learning. The last condition asks us to keep doing all the works on improving the teaching and learning methods to aid student master language skills.

\section{References}

Al-Tahanuwi, A. M. (1996). Kashaf istilahat al-funun wa-al-'ulum. Lebanon: Maktabah Lebanon. http://waqfeya.com/book.php?bid=6153

Asyiah, N. (2016). Pengembangan Peta Konsep Dalam Pembelajaran Bahasa Arab. Jurnal Tarbawi. 1(2) http://ejournal.iainkerinci.ac.id/index.php/tarbawi/article/view/57/56

Buzan, T. (2006). Use Your Head: Innovative Learning and Thinking Techniques to Fulfil Your Potential (Mind Set) (1st Ed). BBC Active. 
Darussalam, G., \& Hussin, S. (2016). Metodologi penyelidikan dalam pendidikan: Amalan dan analisis kajian. Kuala Lumpur: Penerbit Universiti Malaya.

El-Haq, M. A. (2012). Peningkatan Minat Belajar Siswa Dalam Pembelajaran Bahasa Arab Melalui Metode Mind Mapping Di Kelas X Eman Maguwoharjo Sleman [Tesis Sarjana]. UIN Sunan Kalijaga Yogyakarta. http://digilib.uin-suka.ac.id/10153/

Falah, A. (2014). Pembelajaran Bahasa Arab Berbasis Mind Map Untuk Meningkatkan Pemahaman Bahasa Arab Pada Tingkat Madrasah. Arabia, 6(1), 65-82.

Gurlitt, J. (2012). Advance organizer. Encyclopedia of the sciences of learning, 148-151.

Hansen, P. (2009). The most important single factor influencing learning is what the learner already knows - What do the learner know about clouds, precipitation, wind and greenhouse effect; a short review of research from 1883 to 2009. 9Th EMS Annual Meeting, EMS2009-237.

Hussin, Z., Mustapha, N. F., Mezah, C. R., Hajimaming, P. T., \& Rahim, N. A. (2016). The importance of arabic grammar in memorising the quran. GEMA Online Journal of Language Studies, 16(2), 95-110. https://doi.org/10.17576/gema-2016-1602-06

Ismail,W., Jamali, H. N., Ku, A. K. F., \& Rahman, A. A. (2021). Pengajaran kemahiran membaca teks bahasa arab menggunakan teknik unzur qablahu (UQ): Kajian aplikasi teori kognitif (ATK). Attarbawiy: Malaysian Online Journal of Education, 5(2), 105-115.

Ku, A. K. F., Ismail, W., Rosnan, F. N. R., \& Shaharudin, H. N. (2017). Tahap kemahiran bahasa arab dalam kalangan pelajar tahfiz berbantukan mufradat dan uslub al-quran. Tinta Artikulasi Membina Ummah. 3(2), 14-25. http://www.journaltamu.com/wpcontent/uploads/2018/04/TAMU-Vol-32-December-2017-2.pdf

Ku, A. K. F., Rahman, A. A., \& Jamali, H. N. (2014). Tahap kemahiran asas bahasa arab di IPT Malaysia. GSE E-Journal of Education, 1(2), 20-32. https://doi.org/10.13140/RG.2.2.13788.44164

Mohamed, A. K., Muhammad, A., \& Jasmi, K. A. (2004). Permasalahan Pengajaran Nahu Bahasa Arab Kepada Pelajar Sarjana Muda Sains Serta Pendidikan (Pengajian Islam) UTM in Prosiding Fourth International Seminar on LSP in Practise: Responding to Challenges at Fakulti Pengurusan dan Sumber Manusia, Universiti Teknologi on 26 March 2003, pp. 1-12.

http://eprints.utm.my/id/eprint/22607/1/AhmadK2003_PermasalahanPengajaranNa huBahasaArab.pdf

Moreira, M. A. (2011). Meaningful learning: From the classical to the critical view. Meaningful Learning Review, 1(1): 1-15. http://www.if.ufrgs.br/asr/artigos/Artigo_ID1/v1_n1_a2011.pdf

Muhammad, A., Jasmi, K. A.,Nasbon, R., Mustari, M. I., \& Awang, N. F. (2012). Kemahiran membaca dalam pengajaran dan pembelajaran bahasa arab in Seminar Antarabangsa Perguruan dan Pendidikan Islam [SEAPPI2012] (International Seminar on Teacher and Islamic Education [SEAPPI2012]) at Le Grandeur Palm Resort, Senai, Johor Bahru on 8-9 March 2012, pp. 901-910. ISBN 99917-44-89-4.

Mustafa, S. N., Zailani, S., Hashim, U. M., \& Shaadon, Z. (2012). Kajian Meningkatkan Kemahiran Asas Membaca Teks Arab Melalui Kemahiran Membaca Al-Quran dan Kaedah Latih Tubi. Persidangan Kebangsaan Pengajaran \& Pembelajaran Bahasa Arab 2012. https:// suu.com/syazwinaukm/docs/kemahiran_asas_membaca_teks_arab

Rahman, A. A., Jamali, H. N., Ku, A. K. F., \& Isa, S. N. M. (2016). Penguasaan bahan bacaan bahasa arab melalui teknik membaca SQ3R. Journal of Social Sciences and Humanities, 
13(4),

69-80.https://ejournal.uin-

malang.ac.id/index.php/ijazarabi/article/view/12037

Smith, F. (2004). Understanding Reading: A Psycholinguistic Analysis of Reading and Learning to Read (6th ed.). Routledge.

Taimah, R. A. (1986). Al-marji' fi ta'lim al lughah al-arabiah li an-natiqin bi lughah ukhra. Saudi Arabia : Maahad Al-Lughah Al-Arabiah

Vallori, A. B. (2014). Meaningful Learning in Practice. Journal of Education and Human Development, 3(4), 199-209. https://doi.org/10.15640/jehd.v3n4a18

Widodo, W. A. (2016). Penerapan Metode Mind Map Untuk Meningkatkan Minat Belajar Pada Ketrampilan Menulis [Tesis Sarjana]. UIN SATU Tulungagung.

Yulistri. (2015). Uslub Khoritah Al-Aqliyyah wa Taqbiguhu Bi Al-suar Al-Fotografiyah Li Maharatul Kalam Fi Sakan Dakhili ma'Al-fatyan Al-ta'limi. Jurnal IImiah DIDAKTIKA, 15(2), 179-192. http://jurnal.arraniry.ac.id/index.php/didaktika/article/viewFile/579/482

Zulkifli, M. S., Ku, A. K. F., Rahman, A. A., \& Maromar, F. (2020). Buku modul: Al-bayan fi alLughah al-Arabiyah. Kajang: Penerbit Unit Bahasa Arab, Jabatan Bahasa dan Pembangunan Insan, Pusat Pengajian Teras, KUIS. 